\title{
RELAVANSI NILAI-NILAI BUDAYA BUGIS DAN PEMIKIRAN ULAMA BUGIS: Studi atas Pemikirannya dalam Tafsir Berbahasa Bugis Karya MUI Sulsel
}

\author{
Muhammad Yusuf \\ UIN Alauddin Makassar Dpk pada STAI Al Furqan Makassar \\ email: m.yus56@yahoo.com
}

\begin{abstract}
This article investigates the relevance between Bugis culture values and Muslim Scholars' views on gender issues in Bugis Quranic Interpretation by MUI of South Sulawesi. This research uses content analysis. Woman's right to be public leader is not questioned as long it fulfills qualitative and functional criteria. In household affairs, a married couple is a partner with equal responsibilities. The concept of 'iddah emphasizes on religious principle and the culture of self-esteem and purity. The inheritance distribution does not only relate to the right, but also responsibility in order to uphold justice. The expertise of Bugis Muslim scholars to link between Bugis values and its interpretation is not always explicit, some were identifiable implicitly and inherently. The Quranic and local values are two values integrated in giving solution to people. The Bugis people are inspiring to uphold value system and harmonious interaction system in organizing people. Social establishment through the manifestation of core values of culture and the Quranic principle becomes an effective strategy to maintain the identity of community with Islamic doctrine values.
\end{abstract}

Artikel ini membahas relevansi antara nilai-nilai budaya Bugis dan pemikiran ulama Bugis mengenai isu-isu jender dalam Tafsir Berbahasa Bugis Karya MUI Sulawesi selatan. Kajian ini menggunakan pendekatan analisis isi. Hak kepemimpinan perempuan dalam ranah publik tidak dipersoalkan sepanjang memenuhi syarat kualitatif dan fungsional. Dalam rumah tangga, suami dan istri merupakan mitra dengan prinsip sepenanggungan. Konsep 'iddah lebih menekankan prinsip agama dan budaya harga diri,dan makna kesucian. 
Pembagian harta warisan tidak hanya menyangkut hak melainkan juga tanggung jawab demi tegaknya keadilan. Kepiawaian ulama Bugis dalam merelevansikan nilai-nilai budaya Bugis dengan penafsirannya tidak selalu disebutkan secara ekplisit, sebagian diantaranya diketahui dari substansi penjelasannya secara implisit dan inheren. Kearifan Qurani dan kearifan lokal adalah integrasi dua nilai kearifan yang dapat memberikan solusi bagi masyarakat. Masyarakat Bugis dapat memberikan inspirasi bagi tegaknya tata nilai dan pola interaksi yang harmonis dalam menata masyarakat. Pembinaan masyarakat melalui pengejawantahan nilai-nilai utama kebudayaan dan prinsip Qurani adalah strategi yang efektif dalam rangka mempertahankan jati diri suku bangsa dengan nilai-nilai ajaran Islam.

Keywords: Gender, local values, Bugis culture, Muslim Scholars' interpretation.

\section{Pendahuluan}

Masyarakat Bugis, sejak dahulu dikenal memiliki sistem kehidupan dan tata nilai yang mereka pedomani dalam kehidupan berumah tangga dan bermasyarakat. Nilai-nilai utama kebudayaan Bugis itu meliputi kejujuran (lempu'), kecendekiaan (amaccang), kepatutan (assitinajang), keteguhan (agettengeng), usaha (reso), prinsip malu (siri') (Rahim, 2011: 120-144). Nilainilai tersebut diwariskan oleh leluhur Bugis melalui Papangngaja (nasihat) dan Paseng (amanat). Keberadaan nilai-nilai tersebut dapat pula ditemukan sebagiannya pada penjelasan ulama Bugis dalam Tafsir Berbahasa Bugis Karya MUI Sulsel. Penggalian terhadap nilai-nilai kearifan lokal dalam penjelasannya dipahami baik secara eksplisit maupun secara implisit. Hal ini dapat dimaklumi, karena penulisan tafsir tersebut pada dasarnya bertujuan untuk mendekatkan dan memberi pemahaman kepada masyarakat Bugis terhadap ajaran Islam khususnya mengenai isu-isu gender.

Terdapat beberapa isu gender yang seringkali menjadi perdebatan oleh beberapa kalangan. Persoalan yang paling sering muncul sebagai bias gender adalah persoalan hak kepemimpinan perempuan dalam ranah publik, masalah 'iddah, masalah kewarisan, dan lain-lain. Masalah hak kepemimpinan perempuan menjadi bias karena motif politik (kekuasaan), sedangkan masalah 'iddah seringkali menjadi bias karena konstruksi budaya, dan hal tersebut mempunyai akar sejarah dari budaya Arab pra Islam. Adapun masalah kewarisan seringkali terjadi karena motif ekonomi dan budaya. Bias-bias itu terjadi tidak berdiri sendiri, melainkan karena adanya beberapa teks agama (ayat dan hadits) yang secara tekstual mendukungnya. Akan tetapi sebagian ulama mendekati teksteks tersebut dengan pendekatan yang berbeda, yaitu mereka melihat faktor 
eksternal yang membentuk teks, khususnya latar belakang (asbab an-nuzul dan asbab al wurud). Selanjutnya, mereka mencoba menangkap pesan ideal moral teks-teks tersebut. Adapun tulisan ini bertujuan untuk mengkaji pemikiran ulama Bugis mengenai isu-isu gender yang meliputi hak kepemimpinan perempuan, 'iddah, dan kewarisan serta relevansinya dengan nilai-nilai budaya Bugis di dalam tafsir berbahasa Bugis karya MUI Sulsel.

\section{Metode Penelitian}

Pengumpulan data dilakukan dengan mengumpulkan ayat-ayat al Quran secara tematik yang berkaitan dengan gender khususnya mengenai hak kepemimpinan perempuan, 'iddah, dan kewarisan. Sumber-sumber tertulis berupa buku-buku sejarah kebudayaan, kitab-kitab tafsir, seperti tafsir berbahasa Bugis dan tafsir rujukannya, artikel dan disertasi. Sedangkan wawancara dilakukan langsung kepada anggota tim penulis tafsir berbahasa Bugis yang masih hidup.

\section{Budaya Orang Bugis}

Sejak dahulu kala, budaya masyarakat Sulawesi Selatan sudah tercatat di dalam literatur kuno orang Bugis (juga Makassar) yang disebut dengan "Lontarak", yang di dalamnya terdapat ajaran-ajaran yang menceritakan tentang asal muasal kejadian manusia, terjadinya kerajaan, aturan-aturan kehidupan manusia, dan lain-lain. Sejak zaman pra Islam sampai sekarang hal hal tersebut dapat diungkapkan melalui sumber-sumber tertulis sejak abad XIV M. hingga diterimanya Islam sebagai agama yang dianut oleh masyarakat pada awal abad XVII M. Dalam kurun waktu tersebut, sumber yang melukiskan keadaan masyarakat Bugis tersebut hanyalah Lontarak (Mattulada, tahun III: 76).

Berdasarkan catatan sejarah, awal mula suku bangsa yang mendiami pulau ini berasal dari Hindia Belakang. Mereka pertama kali datang sekitar 3000 tahun sebelum Masehi. Inilah yang kemudian disebut Protomelayu (Melayu pertama) yaitu suku bangsa Toraja, yang selanjutnya disusul migrasi kedua, diperkirakan datang sekitar 2000 tahun sebelum Masehi, biasa disebut Deutro Melayu (Melayu Kedua). Mereka yang dimaksud dalam hal ini adalah suku Bugis, Makassar, dan Mandar. Dengan kehadiran pendatang yang kedua tersebut, yang jumlahnya lebih banyak daripada pendatang yang pertama maka pendatang pertama "Protomelayu" tergeser ke daerah pedalaman dan memasuki daerah Tana Toraja, sedangkan Deutro Melayu terpencar atau menyebar dan mendiami daerah pantai (Hamid,1980: 65). 
Suku Bugis mendiami sebagian Bulukumba, sebagian Bantaeng, sebagian Maros, sebagian Pengkajene Kepulauan, Barru, Pare-Pare, Sidenreng Rappang, Pinrang, sebagian Enrekang, dan sebagian Luwu. Suku bangsa Makassar mendiami Gowa, Takalar, Jeneponto, sebagian Maros, sebagian Pangkajene Kepulauan. Suku Mandar mendiami Mamuju, Majene dan sebagian Polmas. Adapun penduduk yang mendiami Kabupaten Enrekang sebagian mengidentifikasikan diri sebagai suku bangsa Massenrengpulu dan Duri. Mereka lebih senang mengklaim dirinya sebagai suku Bugis (Yusuf, 2010: 34).

Sebelum datangnya Islam, masyarakat Bugis memiliki sistem dan tata nilai yang sangat kental. Tata aturan hidup masyarakat Bugis pra Islam, baik yang berkaitan dengan kepercayaan maupun pemerintahan dan kemasyarakatan yang disebut Pangngaderreng (Bugis), Pangngadakkang (Makassar), Pangngadarang (Luwu), Aluk To Dolo (Toraja), dan Ada' (Mandar). Sebelum datangnya Islam, mereka telah meyakini Dewata Seuwae (dewa yang tunggal) (Tim Penulis, 2004: 20), Patotoe (dewa yang menentukan nasib), bagi Bugis dan Luwu. Makassar menyebut Turi A'rana (kehendak yang tinggi), Mandar menyebut Puang Mesa (yang Maha Menghendaki), Toraja Puang Matua (Tuhan yang Maha Mulia). Disamping itu, mereka juga mempercayai adanya Dewa di Gunung Latimojong yang dikenal dengan Dewata Matanrue. Dewa ini kawin dengan E Nyi'li'timo' kemudian melahirkan Patotoe kawin dengan Palingo' dan melahirkan Batara Guru. Batara Guru ini dipercayai oleh sebagian masyarakat sebagai dewa penjelajah di seluruh kawasan Asia yang bermarkas di puncak Himalaya. Sekira satu abad sebelum Masehi, datanglah Batara Guru di Cerekang Malili dengan membawa empat kasta yaitu: kasta Puang, kasta Pampawa Opu, kasta Attana Lang, dan kasta orang kebanyakan (Tim Penulis, 2004: 20).

Dewata Matanrue membawa enam bahasa resmi untuk dipergunakan pada daerah-daerah jelajahannya, yaitu bahasa Tae' atau To'da, bahasa Bare'e, bahasa Mengkokak (Mangkongga'), bahasa Bugis, bahasa Mandar, dan bahasa Tona. Keturunan Batara Guru kemudian terbagi-bagi pada seluruh daerah yang meliputi wilayah bahasanya dan menduduki tempat-tempat strategis dan puncak-puncak gunung tinggi seperti: 1). di puncak Gunung Latimojong disebut Puang ri Latimojong dengan gelar Puang Mattanduk Gellang, Puang Ma'tora Bassi, Dewata Kalandona Buntu, Puang Lajukuna Tanete 2). di puncak Gunung Sinaji disebut Puang ri Sinaji digelar dengan Dewata Mararang Ulunna, Malea Pa pa'barusanna, Borrong Lise Matanna. Di puncak Gunung A'do dinamakan Puang Tontiria'do' 3). di Tasik Mangkombong dinamakan Londong di Langi, 4). 
di Naopo (Dende') dinamakan Datue ri Naopo.

Dari pengawasan Batara Guru melalui puncak gunung tertinggi, ia melantik anak-anak keturunannya pada tiga pusat kerajaan besar, yaitu Payung di Luwu, Somba di Gowa, dan Mangkau di Bone. Selanjutnya, disusul dengan kerajaan-kerajaan bagian seperti Addatuang Sidenreng, Datuk Soppeng, Arung Matoa Wajo, Arajang di Mandar, Puang di Tana Toraja. Kepemimpinan (leadership) dari raja-raja tersebut dimotori oleh karisma dan kesaktian dewa-dewa yang menguasai puncak ketinggian di kawasan Sulawesi Selatan.

Diantara kepercayaan masyarakat Bugis sebelum datangnya Islam yaitu kepercayaan Aluk To Dolo oleh orang Toraja, yaitu kepercayaan adanya sesuatu pengatur semesta alam, Maha Pencipta yang kemudian disebut Puang Matua (Tim Penulis, 2004: 20). Ditemukan pula pada beberapa daerah di Sulawesi Selatan seperti di Tana Toa Kajang Bulukumba, di Onto yang terdapat di lereng gunung Bantaeng dan desa-desa pegunungan terpencil di Camba dan Barru. Kepercayaan mereka itu dikenal oleh masyarakat luar dengan kepercayaan agama "Patuntung". Agama Patuntung mempercayai adanya sesuatu yang Maha Kuasa, Maha Tunggal dengan berbagai istilah atau nama, misalnya Turia" a'ra'na (yang berkehendak).

Kepercayaan serupa di Sidenreng Rappang, yaitu suatu kepercayaan yang disebut Towani Tolotang, yaitu suatu kepercayaan yang meyakini adanya kekuasaan alam yang tinggi yang mereka namakan "To Palanroe" (yang mencipta), Dewata Seuwae (Tuhan yang tunggal). Dalam urutan nama-nama yang mengandung kedewaan terdapat nama Batara Guru, Sawerigading, dan Galigo. Adapun yang menjadi "kitab suci" mereka yaitu "Mitologi Galigo" dan mereka mempercayai kebenaran yang terdapat dalam kitab suci sebagai kepercayaan yang tinggi (Tim Penulis, 2004: 23-24). Dari situlah mereka berpedoman tentang tata cara hidup kemasyarakatan seperti perkawinan antara mereka, upacara dalam hidup keagamaan yang mereka lakukan dengan sangat ketat. Pada zaman dahulu, orang Bugis tidak menguburkan mayat mereka, melainkan dibakar dan dimasukkan ke dalam guci. Pembakaran mayat tersebut ada kaitannya dengan kepercayaan agama To-Lotang atau To-Ani yang diduga asalnya dari 'Ware' Luwu" sebagai tempat asalnya Mitologi Galigo.

Islam tersebar dan diterima di Sulawesi Selatan oleh masyarakat baik pada garis atas (raja) dan garis bawah (rakyat) karena pola-pola pendekatan yang sesuai dengan bibit spiritual dan ritual yang sudah ada sebelum masuknya Islam. Terdapat tiga pendekatan yang ditempuh, yaitu: pertama, pendekatan hukum (fikih), dalam hal ini Datuk Ribandang mengunjungi daerah Makassar 
dan Bugis yang kuat melakukan judi, minum ballo (khamar), zina, dan riba. Kedua, pendekatan ilmu kalam, dengan cara Datuk Patimang mengunjungi daerah-daerah Bugis yang kuat melakukan kepercayaan lama yang meyakini atau menganggap bahwa Tuhan Yang Maha Esa itu adalah Dewata Seuwae, yaitu suatu kepercayaan yang sekarang ini dikenal dengan Mitologi Galigo. Datuk Patimang lebih mengutamakan pengajaran tauhid, yaitu pemahaman tentang sifat-sifat Allah SWT untuk menggantikan kepercayaan lama menjadi keprcayaan tauhid kepada Allah SWT yang tercermin lewat dua kalimat persaksian (syahadat). Ketiga, pendekatan ilmu tasawuf. Ini lebih fokus dilakukan oleh Datuk Ritiro. Ia mengunjungi daerah-daerah Bugis yang kuat berpegang pada ilmu kebatinan dan ilmu sihir, kemudian menggantinya dengan ajaran tasawuf yang benar (Tim Penulis, 2004: 67). Masyarakat sebagai sasaran dakwah ( $\operatorname{mad}^{\prime} u$ ) terutama masa awal Islam banyak yang memiliki ilmu kebatinan seperti sihir, kekebalan, dan santet (doti) (Ramli, 2003: 47-48). Sejak awal kedatangan Islam di Sulawesi Selatan, sinergi pemerintah dan ulama dalam membina masyarakat selalu terjalin dengan baik, yang pembinaannya senantiasa bertumpu pada nilai-nilai Islam dan kearifan nilai-nilai budaya lokal.

Dari segi budaya, masyarakat Bugis mempunyai nilai budaya sibaliperri' (sepenanggungan, bermitra), sipurepo' (berat sama dipikul), dan sebagainya. Sedangkan dalam konteks 'iddah berkaitan dengan budaya siri' (budaya malu dan harga diri) dan asitinajang (asas kepatutan), lempu' (kejujuran), dan lainnya. Selain itu, dalam masalah pembagian pusaka (kewarisan) erat kaitannya dengan budaya mallempa' (memikul) dan majjujung (menjunjung), yang artinya anak laki-laki mempunyai hak (warisan) sekaligus kewajiban mengayomi saudaranya yang perempuan, sedangkan anak perempuan mempunyai hak (warisan) dan bertanggung jawab atas dirinya. Dalam menerapkan warisan ini, masyarakat Bugis juga merujuk pada assitinajang (asas kepatutan) baik dalam takaran budaya maupun dalam takaran ajaran agama, yaitu patut menurut budaya dan agama.

\section{Ulama Bugis dan Tafsir Berbahasa Bugis}

Tafsir berbahasa Bugis karya tim MUI Sulsel merupakan karya tafsir kolektif dilihat dari penulisnya. Para ulama yang tergabung dalam proses penulisannya; yaitu K.H.Abd. Muin Yusuf (1920-2004), K.H. Makmur Ali (1925-200 M.), K.H. Hamzah Manguluang (1925-1998 M), K.H. Muhammad Djunaid Sulaiman (1921 M/1339 H.-1996 M/1417 H), H. Andi Syamsul Bahri (1. 1955 M), M.A., K.H. Mukhtar Badawi (t.d.) (MUI Sulsel, 1988: 4). Mereka 
semua merupakan suku Bugis dan pandai bahasa Bugis Lontarak. Selain nama-nama tersebut, masih ada beberapa ulama yang merupakan kontributor, namun tidak dicantumkan namanya karena pertimbangan tertentu dan atas dasar kesepakatan (Wajdi, 2010: 89).

Tafsir ini diberi judul dalam bahasa Arab Tafsir al Quran al Karim dan judul dalam bahasa Bugis "Tafesere Akorang Mabbasa Ogi". Penulisannya diprakarsai oleh tim MUI Sulawesi Selatan, diketuai oleh K.H. Abd. Muin Yusuf. Awalnya, buku tafsir tersebut terdiri dari 10 jilid, kemudian dicetak ulang dan diperbanyak oleh MUI Sulawesi Selatan. Pada cetakan selanjutnya terjadi perubahan pada jumlah jilidnya menjadi 11 jilid. Pada awalnya, 10 jilid itu memuat 3 juz, tetapi karena jilid ke-10 dinilai terlalu tebal, maka dibagi menjadi 2 jilid (Bahri, 2008). Tafsir ini terbit sejak 1988 dan lengkap 30 juz pada tahun 1996 (Yusuf, 2012: 93).

Penulisannya merujuk pada kitab-kitab tafsir otoritatif, yang dibagi pada dua kategori yaitu rujukan primer dan rujukan sekunder. Kitab-kitab tafsir rujukan primer adalah sebagai berikut: 1. Tafsir al Maragi karya Ahmad Mustafa al Maragi, ditulis pada tahun $1361 \mathrm{H} / 1941 \mathrm{M}$. yang terdiri atas 30 juz dalam 10 jilid. 2. Tafsir al Qasimi yang disusun oleh Jamaluddin al Qasimi, 3. Tafsir Ibn Kasir, yang juga sering disebutkan Tafsir al Quran al 'Azhim dtulis oleh Abu al Fida' Isma'il ibn 'Umar ibn Kasir al Qurasyi al Dimasyqi (700-774 H), lebih dikenal dengan nama Ibn Kasir sebanyak 8 juz. 4. Tafsir al Quran al Karim yang disusun oleh al Baidawi. Sedangkan kitab tafsir rujukan sekundernya, sebagai berikut: Tafsir at Thabari dikenal sebagai tafsir bi al ma'sur yang mendasarkan penafsirannya pada riwayat-riwayat dari Nabi, sahabat, dan dari tabi'in. Tafsir al Qurthubi, karya Abu 'Abdillah Muhammad ibn Ahmad al Anshari al Maliki al Qurthubi (w.671 H./1273 M.), al Tafsir al Wadhih, Shafwat al Tafasir, al Durr al Mantsur, dan al Muntahnab fi Tafsir al Quran al Karim (MUI Sulsel/I, 1988: 4). Sumber-sumber rujukan tersebut disepakati melalui rapat beberapa kali (Yusuf, 2010: 231). Hal ini dilakukan untuk memberikan nuansa penjelasan yang bervariasi dan berbagai alternatif pemahaman.

\section{Beberapa Isu Gender Dan Relevansinya Dengan Nilai-Nilai Budaya Bugis}

Berdasarkan penelusuran, aspek-aspek yang mempunyai kesesuaian dengan budaya Bugis meliputi 'iddah, hak kepemimpinan perempuan, dan kewarisan. Ketiganya seringkali menjadi objek perdebatan dikalangan intelektual.

\section{Hak Kepemimpinan Perempuan}


Salah satu persoalan yang sering menjadi perbicangan dikalangan intelektual Islam mengenai perempuan adalah masalah boleh tidaknya perempuan menjadi pemimpin. Ada tiga dasar yang selalu dijadikan pijakan untuk menegaskan bahwa perempuan tidak boleh menjadi pemimpin, yaitu QS an Nisa: 34, sebuah hadits yang secara eksplisit menggambarkan sikap pesimis Rasulullah SAW akan keberhasilan kepemimpinan seorang perempuan, dan sebuah hadits yang menerangkan tentang rendahnya intelektualitas para perempuan.

Penafsiran ulama Bugis terhadap kata qawwam pada QS an Nisa: 34 diartikan "pelindung" dan "pemimpin". Dengan demikian, tugas kepemimpinan dalam rumah tangga tetap berada di tangan suami. Pandangannya ini didasarkan pada dua alasan yaitu: 1) karena adanya keistimewaan yang berbeda pada masingmasing jenis kelamin, yaitu laki-laki memiliki bentuk fisik yang sempurna, maka dalam konteks qawwamah keistimewaan yang dimiliki oleh laki-laki lebih sesuai untuk menjalankan tugas tersebut dibandingkan perempuan dan; 2) karena laki-laki atau suami memberi nafkah kepada isterinya. Sementara perempuan menjalankan tugasnya sesuai dengan fitrahnya sebagai perempuan yaitu: hamil, melahirkan, memelihara dan mengatur di dalam rumah tangga. Jadi, penafsiran para ulama Bugis di atas menempatkan suami sebagai penanggung jawab dalam wilayah publik, yaitu mencari nafkah (sappa laleng atuwong). Sementara, perempuan dalam wilayah rumah tangga sebagai ibu (indo' ana') kewajibannya mengasuh anak, memasak, dan mencuci.

Mengenai kepemimpinan perempuan dalam ruang publik, ulama Bugis tidak menguraikan pandangannya terhadap hal ini (MUI Sulsel, 1988: 269). Bisa jadi, mereka setuju dengan diberikannya peluang bagi perempuan untuk berkiprah seperti halnya dengan laki-laki termasuk dalam hal kepemimpinan dalam wilayah publik. Indikasi lainnya adalah mereka tidak mengutip hadits yang sering dijadikan dalil untuk menolak perempuan tampil di wilayah publik menjadi pemimpin (at Turmudzi, $2000 \mathrm{M} / 1421 \mathrm{H}$ : 263). Demikian pula tidak dikomentari persoalan ini, bisa jadi melihat konteks masyarakat Bugis yang tidak selamanya menempatkan perempuan pada posisi yang lebih rendah. Bahkan, dalam sejarah masyarakat Bugis menempatkan perempuan posisi yang tinggi sama dengan posisi laki-laki, sebagaimana tergambar lewat ungkapan orang Bugis:

"mauni orowane namakkunrai sifa'na makkunrai mui. Mauni makkunrai sifa'na naorowane sifa'na orowane mui". 
Maksudnya, meskipun dia laki-laki, jika memiliki sifat perempuan dia adalah perempuan; dan perempuan, yang memiliki sifat kelaki-lakian, adalah laki-laki (Pelras, 2006: 188).

Dalam wilayah publik, kepemimpinan tidak selalu harus di tangan lakilaki, sedangkan dalam konteks masyarakat Bugis, kriteria pemimpin itu lebih pada syarat-syarat kualitatif, yang bisa saja dimiliki oleh laki-laki dan perempuan. Nilai-nilai budaya masyarakat Bugis menekankan pada integritas, intelektual, dan kompetensi personal. Kompetensi intelektual berupa kecendekiaan (amaccang). Sedangkan kompetensi personal meliputi kejujuran (lempu'), keteguhan (agettengeng), usaha yang gigih (reso), dan kepatutan (asitinajang) itu merupakan akumulasi dari beberapa pertimbangan maslahat dan mudaratnya berdasarkan kemampuan personal, integritas, dan intelektualitas, serta resistansi calon pemimpin.

Berbeda halnya dengan posisi perempuan dalam rumah tangga, masyarakat Bugis menempatkan perempuan (isteri) sebagai mitra suami (zawj) dalam membangun rumah tangga. Penafsiran yang sering diperdebatkan oleh banyak kalangan seputar ayat-ayat yang bertalian dengan kesejajaran laki-laki dan perempuan, menunjukkan laki-laki dan perempuan itu berbeda, tetapi perbedaan itu justru menunjukkan kesempurnaan jika ditempatkan secara proporsional. Dalam konsep sibaliperri' dengan istilah 'ringan sama dijinjing berat sama dipikul', semua pihak proaktif dan mengambil peran secara bersama-sama.

\section{'Iddah}

Perempuan yang ditinggal suaminya, baik karena perceraian maupun karena kematian, ia berkewajiban menjalani "iddah. "Iddah berasal dari kata "'adad" yang bermakna "hitungan" atau "perhitungan”. Istilah 'iddah digunakan dalam konteks ini karena di dalamnya terdapat unsur bilangan, yaitu harihari haid dan masa-masa suci bagi seorang perempuan yang ditalak. Secara terminologis, 'iddah didefinisikan sebagai masa penantian bagi seorang wanita, yaitu satuan waktu (fase) yang di dalamnya ia tidak boleh dipinang secara terang-terangan dan menerima pinangan dari lelaki lain setelah wafat suaminya atau setelah diceraikannya ('Abidin, t.th.: 502. \& az Zahabi, 1968: 347). Batas masa tunggu tersebut berbeda-beda, sesuai dengan cara ia ditinggal oleh suaminya. Al Quran membedakan antara 'iddah perempuan yang ditinggal mati suaminya ("tawaffa 'anha zaujuha) dengan perceraian yang bukan karena kematian suaminya (gairu mutawaffa 'anha zaujaha). Kondisi rahimnya ketika 
diceraikan adakalanya sedang terbuahi dan adakalanya dalam keadaan kosong. Ada pula perempuan yang diceraikan pada saat memasuki masa monopause, ada yang sudah digauli dan ada yang belum digauli.

Bagi perempuan yang bercerai karena ditinggal mati suaminnya, ia harus menjalani masa 'iddah selama 4 bulan 10 hari (QS al Baqarah: 234), bagi mereka yang tidak ditinggal mati oleh suaminya 'iddahnya selama 3 kali quru' (QS al Baqarah: 228), bagi perempuan yang sedang hamil 'iddahnya sampai melahirkan (QS at Thalaq: 4), dan bagi perempuan yang sudah memasuki masa monopause 'iddahnya 3 bulan dengan catatan jika terjadi keragu-raguan (QS at Thalaq: 4), demikian juga yang belum haid. Perempuan yang diceraikan dan belum digauli, tidak ada 'iddah atasnya (QS al Ahzab: 49).

Adapun 'iddah bagi seorang isteri yang ditalak, terdapat dalam al Quran:

"Wanita-wanita yang ditalak hendaklah menahan diri (menunggu) tiga kali quru'. Tidak halal bagi mereka menyembunyikan apa yang diciptakan Allah dalam rahimnya, jika mereka beriman kepada Allah dan hari akhirat. Dan suami-suaminya berhak merujukinya dalam masa menanti itu, jika mereka (para suami) itu menghendaki ishlah. Dan para wanita mempunyai hak yang seimbang dengan kewajibannya menurut cara yang ma'ruf. Akan tetapi para suami mempunyai satu tingkatan kelebihan daripada isterinya. Dan Allah Maha Perkasa lagi Maha Bijaksana" (QS al Baqarah: 228)

Yang dimaksud dengan "wanita-wanita yang ditalak" pada ayat tersebut, adalah wanita-wanita yang belum mengalami manopouse, yang telah bercampur dengan suaminya, kemudian ditalak tidak dalam keadaan hamil (MUI Sulsel, 1988: 330). Hal ini dipahami demikian, karena masa tunggu wanita yang sedang hamil adalah sampai ia melahirkan anaknya (QS at Thalaq: 4), wanita monopouse dan wanita yang belum haid, masa tunggunya adalah tiga bulan (QS at Thalaq: 4). Sedangkan wanita yang dikawini tanpa bercampur lalu cerai, maka tidak diwajibkan atasnya masa tunggu (QS al Ahzab: 49). Atas dasar itulah, perempuan yang ditalak diwajibkan menunggu untuk tidak kawin selama interval waktu tersebut.

Penggunaan anak kalimat "menunggu dengan menahan diri mereka" mengisyaratkan bahwa wanita-wanita tersebut tidak sekedar menunggu, tetapi penantian itu dilakukan atas kesadaran, bukan karena paksaan atau tekanan dari luar, karena mereka sendiri yang paling mengetahui persis masa suci dan haid yang mereka alami (Mursalim, 2008: 161). Dalam keadaan demikian, dibutuhkan kejujuran (lempu') dari wanita tersebut.

Orang Bugis dikenal dengan prinsip siri' (malu) dan lempu' (kejujuran), 
paccing (kesucian). Pandangan ulama Bugis didasarkan pada sebuah hadits Nabi, sebagaimana dikutip, yaitu mengingatkan kepada seorang isteri yang ditinggal mati oleh suaminya, agar tetap menjaga dirinya, tidak keluar rumah mempertontonkan dirinya sehingga bisa mengundang syahwat laki-laki lain. 'Iddah dan ihdad menuntut kejujuran (lempu') tentang apa yang ada dalam rahim (haid dan janin), serta menjaga kesucian diri dan keturunan yang sejalan dengan nilai "paccing" (kesucian) dalam budaya Bugis.

Pandangan di atas juga sejalan dengan budaya siri' (prinsip malu) dan pesse (solidaritas). Konsep ini, bagi masyarakat Bugis adalah sebagai suatu norma yang sangat dihormati, karena hal itu merupakan bukti bahwa seorang isteri dapat menjaga kesucian diri dan kehormatannya. Dalam kaitan ini, syair orang Bugis menyebutkan: "Duwai kuala sappo; unganna panasae, belona kanukue" Artinya: "Dua (hal) yang kujadikan pagar (pelindung diri dan kehormatan), bunga nangka dan hiasan kuku” (Abdullah, 1985: 37).

Kata 'panasa' pada unganna panasae yang sinonim dengan kata "lempu". Bila diberi tekanan glottal stop (') pada suku kata terakhir menjadi lempu', maka kata itu berubah maknanya menjadi 'kejujuran'. Kata "belona kanukue”, digunakan untuk hiasan kuku (belo kanuku) yang disebut pacci. Kata pacci, bila mendapat tambahan bunyi "ng" pada akhir kata pacci menjadi paccing, maka kata itu berubah arti menjadi tidak ternoda, bersih, atau suci. Dengan demikian, dapat diartikan "hanya dua yang bisa dijadikan pagar (pelindung diri) yaitu kesucian dan kejujuran." Ini memberikan pemahaman bahwa wanitawanita yang ditinggal mati oleh suaminya, demi terjaganya sebuah kesucian, maka tidak diperkenankan keluar rumah selama masa 'iddah tersebut tanpa alasan yang membolehkannya.

Mengenai penetapan'iddah terdapat dua pendapat; ada yang memahami dengan sangat ketat, sehingga pada hal yang sangat kecil sekalipun, dilarang bagi seorang isteri untuk dilakukan, misalnya, memakai sabun mandi, wangiwangian, melarang berbicara, (termasuk menerima telepon dari lelaki yang bukan mahramnya), bahkan dilarang memakai jam tangan karena jam itu dinilai sebagai perhiasan. Bagi wanita yang ditinggal mati oleh suaminya, ia wajib menahan dirinya untuk tidak berdandan dan tetap berada di rumah selama masa 'iddah itu (Mukhlis, 1986: 51). Sementara yang lainnya, ada yang mamahami dengan lebih toleran, sehingga dalam waktu beberapa hari saja, isteri yang ditinggal suami, sudah boleh keluar rumah, menghadiri acara dengan berdandan, seakan-akan mengundang laki-laki lain untuk segera menikahinya, dan seakan-akan telah melupakan suka dan dukanya bersama suami yang baru 
meninggal. Hal itu tentu saja berpotensi menyinggung perasaan keluarga suami. Pandangan ini sejalan dengan prinsip Bugis asitinajang (asas kepatutan), dan diperkuat oleh budaya sipakatau (saling menghargai).

Penafsiran para ulama Bugis menyatakan bahwa penetapan 'iddah yang sangat ketat mengikuti pendapat pertama. Hal ini seakan ingin berkata kepada masyarakat bahwa para isteri yang ditinggal mati oleh suaminya, secara moral dan tradisi, agar mereka dapat terpelihara dari hal hal yang dapat menimbulkan fitnah. Oleh karena itu, perempuan yang suaminya meninggal dan masih dalam keadaan masa berkabung, tetap berada di rumah. Ini bertujuan memberikan petunjuk kepada pihak perempuan untuk tetap menjaga harkat dan martabatnya, apalagi jika dikaitkan dengan konteks masyarakat Bugis yang sangat kuat memegang teguh ade' (adat) (MUI Sulsel/I, 1988, 357). Menurut pemahaman masyarakat Bugis bahwa ade' sebagai esensi manusia, ade' itulah yang menyebabkan seseorang disebut manusia. Seorang yang tidak mengetahui, menghayati, dan memerankan diri dengan ade' maka tidak dapat disebut manusia. Dari ade' itulah manusia berpangkal, tanpa ade' yang menjadi pangkal kemanusiaan, maka apa yang disebut lempu' (kejujuran), takwa kepada Allah dan mempertinggi siri' sebagai nilai dan martabat kemanusiaan, tidak mungkin terwujud.

Siri' (prinsip malu, harga diri) harus ditegakkan bersama-sama, ia tidak mungkin dipandang hanya kewajiban satu pihak saja. Dalam Lontarak Bugis dinyatakan 'Naiyya riasengnge allaibinengeng iyyapa nasokku' sipatangerengnge nasiolong elo nasipakainge rigau patujue nasiakkasiriseng risininna gau maka riposirie" yang memiliki arti "Kehidupan suami-istri (keluarga), hanya bisa sempurna apabila kedua belah pihak saling memberi pertimbangan, lalu sejalan kehendak, dan saling menjaga malu dalam hal-hal yang benar, dari semua perbuatan yang benar, dan saling menjaga harga diri dari semua hal yang dapat merusak malu"

Hal ini sejalan dengan firman Allah SWT pada QS al Baqarah: 187, bahwa istri dan suami dianalogikan dengan pakaian, yang antara lain fungsinya sebagai alat penutup anggota tubuh yang lazim ditutup agar tidak tampak dan tidak memalukan. Sebab, terdapat kesamaan fungsi antara pakaian dan fungsi pasangan suami-istri, yaitu mereka saling melindungi dan menjaga aib yang memalukan. Jadi, siri' suami harus dijaga oleh isteri, dan sebaliknya, siri' isteri harus dijaga oleh suami. Satu sama lainnya harus saling memelihara dan menghormati untuk mencegah timbulnya perbuatan atau tindakan yang memalukan (mappakasiri'), perasaan malu (masiri'), dipermalukan (ripaksiri') 
(Matthes, 1874: 43) baik terhadap pasangan suami dan istri maupun kepada pihak keluarganya.

'Iddah adalah ajaran agama yang sangat manusiawi, di samping sebagai ketentuan agama, 'iddah juga sebagai rasa penghormatan kepada keluarga suami atau didasari oleh moral agama, karena dapat dibayangkan perasaan keluarga sang suami bila isteri yang ditinggalkannya apabila baru beberapa hari kemudian ia berkawin lagi. Jadi, penetapan hukum Islam senantiasa mempertimbangkan aspek eksternal (budaya). Dalam nilai-nilai budaya Bugis ini disebut asitinajang (kepatutan) (Rahim, t. th. 173). Jadi, bagi orang Bugis yang masih tetap menjunjung tinggi nilai ini, mereka dengan mudah menjalani masa 'iddah.

\section{Kewarisan}

Wacana pemikiran kesetaraan gender dalam Islam menempatkan masalah pembagian harta warisan sebagai salah satu topik perdebatan yang hangat. Pada tahun 1980 muncul adanya gagasan agar dalam pembagian harta warisan umat Islam Indonesia memberikan bagian yang sama antara laki-laki dan perempuan (Syadzali, 1995: 97). Gagasan ini antara lain merujuk pada perbedaan konteks ketika ayat tersebut diturunkan dengan konteks yang ada saat ini. Akan tetapi, gagasan ini ditentang keras oleh para ulama di Indonesia dengan alasan bertentangan dengan ayat-ayat al Quran.

Berangkat dari perbedaan dalam menyikapi hal tersebut, maka dengan penelusuran penafsiran yang dituangkan komunitas ulama Bugis di dalam karya tafsirnya mengenai hal tersebut, dimaksudkan untuk menggali nilai-nilai kearifan lokal masyarakat Bugis yang terkait dengannya. Salah satu ayat yang sering dijadikan pembicaraan mengenai pembagian warisan yaitu:

"Allah mewasiatkan kamu untuk anak-anakmu. Yaitu bagian seorang anak laki-laki sama dengan bagian dua orang anak perempuan...." (QS an Nisa: 11)

Terhadap ayat di atas, hampir semua mufasir mengakui bahwa secara tekstual pembagian warisan untuk anak laki-laki sebanyak dua kali lipat pemberian untuk anak perempuan, termasuk pandangan ulama Bugis, "Hakna nariwereng ana' orowane-e bagian leppiduana bagianna ana' makkunraiye nasaba iyaro ana' buranewe nabalancai alena. Parellutoi nabalancai bainena. Naiya ana makkunraiye alenami nabalancai, narekko purani mallakkai ribalancaisi rilakkainna" (MUI Sulsel, 1988: 217), yang artinya "Anak laki-laki berhak mendapatkan bagian warisan dua kali lipat dari bagian anak perempuan, karena anak laki-laki memberikan nafkahi dirinya dan menafkahi isteri dan keluarganya. 
Sementara, anak perempuan tidak ada tanggungannya dan apabila sudah menikah maka dia yang dinafkahi”.

Dari penjelasan di atas, tafsir berbahasa Bugis masih sangat kuat memperpegangi kaidah "al "Ibrah bi 'umum al Lafzh la bi khusus al sabab" (yang menjadi patokan adalah keumuman lafaz bukan kekhususan sebab (latar belakang)”. Seakan para ulama Bugis ingin mengatakan bahwa pembagian harta warisan itu harus disesuaikan dengan petunjuk-petunjuk agama, sebagaimana dituangkan dalam nash, yaitu al Quran dan hadits Nabi. Pembagian warisan antara laki-laki dan perempuan, yaitu 2:1 masih sangat relevan dengan konteks budaya masyarakat pada saat itu. Hal ini bisa dipahami bahwa masyarakat Bugis, dalam pemahaman mereka mengenai pembagian harta warisan mengikuti syariat. Dalam kultur masyarakat Bugis dikenal ungkapan: "mallempa' buranewe, majjujung makkunraiye" (laki-laki memikul (membawa dua), perempuan menjunjung (membawa satu) meskipun dalam prakteknya seringkali hanya mengikuti apa yang menjadi kesepakatan antara pihak keluarga, sehingga pembagiannya dibagi rata. Anak laki-laki dan anak perempuan mendapatkan bagian yang sama. Bahkan, kadang-kadang anak perempuan mendapatkan lebih banyak karena kultur sebagian masyarakat Bugis yang memberikan anak perempuan berupa tempat tinggal (rumah, ruko). Masyarakat Bugis biasanya membagi harta warisan menurut tradisi yang sudah berjalan. Jika dalam pembagian itu terasa adanya ketidakadilan, maka dapat diselesaikan dengan beberapa alternatif; dibagi 1:1, 2:1, atau menurut tradisi. Alternatif terakhir ini biasanya perempuan mewarisi rumah, dan anak laki-laki mewarisi harta yang lain.

Pandangan para ulama Bugis di atas sama dengan pandangan mufasir lainnya. Pemberian warisan untuk anak laki-laki sebanyak dua kali lipat dari pemberian untuk anak perempuan, bukan saja karena anak laki-laki ketika menikah berkewajiban memberi mahar dan nafkah kepada isteri dan keluarganya, melainkan juga karena laki-laki secara umum memiliki keistimewaan dalam bidang pengendalian emosi dibandingkan dengan perempuan. Ini menunjukkan bahwa pengendalian harta atas dasar pertimbangan akal harus didahulukan daripada pengendaliannya atas dasar emosi (Shihab, 2005: 262). Dapat pula teks itu dipahami bahwa 2:1 adalah isyarat keadilan gender dalam pembagian kewarisan. Dua adalah bagian maksimal yang dapat diwarisi oleh anak laki-laki, dan satu adalah jumlah maksimal yang harus diperoleh oleh anak perempuan. Dengan demikian, pembagian dapat dibagi rata $(1: 1)$ jika hal itu tidak menimbulkan masalah atau resiko negatif, apalagi jika hal itu 
lebih menunjukkan sebuah bentuk keadilan.

Atas dasar maslahat dan keadilan pula, teks ayat itu juga dapat diterapkan dengan merujuk pada maslahat jika suatu masyarakat memberlakukan secara tekstual 2:1 dengan catatan bahwa jika saudara perempuan tidak menikah, yang berarti tidak memperoleh mahar, maka saudara laki-laki yang mendapat lebih banyak itu memikul (mallempa') tanggung jawab menafkahi saudara perempuannya. Dalam konteks masyarakat Bugis nilai assitinajang (kepatutan) agar tidak menimbulkan kecemburuan dan perselisihan. Disebutkan di dalam QS an Nisa: 32 bahwa untuk tidak menimbulkan rasa kecemburuan antara kedua belah pihak al Quran mengingatkan:

"Dan janganlah kamu iri terhadap apa yang dikaruniakan oleh Allah kepada sebagian kamu dari sebagian yang lain. (Karena) bagi laki-laki ada bahagian dari pada apa yang mereka usahakan, dan bagi wanitapun ada bagian dari apa yang mereka usahakan dan mohonlah kepada Allah sebagian dari karunia-Nya. Sesungguhnya Allah Maha Mengetahui segala sesuatu” (QS an Nisa: 32).

Keadilan dan iman adalah kunci untuk mengakhiri perseteruan mengenai pembagian harta warisan. Iri dapat terjadi karena adanya perlakuan yang tidak adil. Rasa ketidakadilan itu juga dapat muncul karena keserakahan, dan dapat diselesaikan jika iman kepada Allah telah menjadi penetralisirnya. Ayat di atas mengatakan bahwa bagi pihak perempuan tidak bisa merasa iri terhadap apa yang didapatkan oleh laki-laki. Demikian sebaliknya, pihak laki-laki tidak bisa juga merasa iri terhadap apa yang didapatkan oleh perempuan (MUI Sulsel/II, 1988: 262). Untuk menghindari perasaan saling iri, dibutuhkan pembagian yang adil disamping iman, karena dibalik ketetapan Allah tersebut pasti ada maslahat.

\section{Simpulan}

Kepiawaian (amaccang) dan keuletan bekerja (reso) ulama Bugis telah menghasilkan karya nyata berupa tafsir al Quran secara kolaboratif (kolektif) yang mempertahankan khazanah lokal, bukan hanya dari segi bahasa Bugis Lontarak yang digunakannya, melainkan juga substansi penjelasannya yang sarat dengan nilai-nilai kearifan lokal. Pemikirannya memuat penjelasan yang memiliki relevansi dengan khazanah budaya lokal orang Bugis. Hal ini lebih memungkinkan untuk diterima dan diaplikasikan secara efektif, sebab dapat memberikan solusi bagi masyarakat Bugis khususnya dalam menghadapi berbegai kemelut pemikiran kontemporer dan tantangan iptek modern.

Di tengah pergulatan intelektual dalam perspektif global, ternyata belum 
mampu memberikan solusi terhadap berbagai tantangan. Jati diri sebuah suku bangsa kini terusik, bahkan dipaksa mencari dan mengikuti berbagai tawaran budaya yang lain. Akibatnya, terjadi disharmoni dan kekacauan yang gawat. Padahal, nilai kearifan dan budaya lokal sesungguhnya merupakan solusi yang paling dekat dengan kehidupan masyarakat. Oleh kerena itu, integrasi antara khazanah kearifan lokal yang relevan dengan ajaran Islam yaitu al Quran yang dikemas oleh ulamanya sendiri tentu lebih efektif.

\section{Saran}

Nilai-nilai utama kebudayaan Bugis kiranya dapat menjadi salah satu solusi alternatif dalam menyikapi dampak kemajuan iptek modern dan globalisasi agar tidak kehilangan jati diri. Ilmuwan dan ulama mempunyai tanggung jawab dalam memberikan pencerahan terhadap nilai-nilai kearifan yang terintegrasi antara Islam dan kearifan lokal tanpa alergi dengan kemajuan iptek dan globalisasi, karena justru nilai-nilai utama kebudayaan Bugis dan semangat ajaran al Quran mendorong masyarakat untuk menjadi pioner perkembangan dan kemajuan iptek. Hal tersebut tentu tidak hanya berlaku bagi masyarakat Bugis saja, tetapi suku bangsa yang ratusan jumlahnya di Indonesia masing-masing mempunyai nilai-nilai kearifan budaya yang mungkin dapat diintegrasikan dengan nilai-nilai qurani dan diamalkan dalam kehidupan sehari-hari. Dakwah melalui penafsiran ulama Bugis merupakan contoh konkret nyata yang patut dijadikan inspirasi dalam mengatasi krisis nilai-nilai budaya dan nilai-nilai kemanusiaan.

\section{Daftar Pustaka}

Abdullah, Hamid. 1985. Manusia Bugis-Makassar: Suatu Tinjauan Historis terhadap Pola Tingkah Laku dan Pandangan Hidup Bugis-Makassar. Jakarta: Inti Dayu.

al Dzahabi, Muhammad Husain. 1968. Al Syar'iah al Islamiyah: Dirasah Muqranah baina Ahl al Sunnah wa Mazhab al Ja'fariyah. Mesir: Dar al Kutub al Haditsah.

Bahri, Andi Syamsul, Anggota Tim Penulis Tafsir Berbahasa Bugis. Wawancara. tanggal 29 Juli 2008 di Malaysia.

Departemen Pendidikan dan Kebudayaan. 1982. Upacara Tradisional Sulawesi Selatan. Ujung Pandang: Dirjen Kebudayaan. 
Hamid, Abu. 1980. Selayang Pandang Uraian tentang Islam dan Kebudayaan dalam Buku Bugis Makassar dalam Peta Islamisasi di Indonesia. Ujungpandang: IAIN Alauddin.

Ibn 'Abidin. t.th. Hasyiyah Radd al Mukhtar 'ala al Dur al Mukhtar. Jilid III. Beirut: Dar al Fikr.

M. Ramli, Asep Syamsul. 2003. Jurnalistik Dakwah: Visi dan Misi Dakwah bi al Qalam. Bandung: PT Remaja Rosdakrya.

Matthes, Benjamin Frederik. 1874. Boegineesche Chrestomathie. dalam "Bicaranna Latoa". Amesterdam: Het Nederlan Bijbelgnootschap.

Mattulada. tahun III. Sulawesi Selatan Pra Islam dalam Bultetin Yaperna. No. 12.

MUI Sulsel. 1988. Tafesere Akorang Mabbasa Ogi. Jilid I-XI. Ujung Pandang: MUI Sulsel.

Mukhlis (ed). 1986. Dinamika Bugis-Makassar. t.tp: Pusat Latihan Penelitian Ilmu-Ilmu Sosial dan YIIS.

Mursalim. 2008. Tafsir Bahasa Bugis, Tafsir al Quran al Karim Karya Majelis Ulama Indonesia (MUI) Sulawesi Selatan; Kajian terhadap PemikiranPemikirannya [Disertasi]. Jakarta: UIN Syarif Hidayatullah.

Mursalim. 2012. Tafsir al Quran al Karim Karya MUI Sulsel. Al Ulum, Jurnal Studi-Studi Islam. Volume 12, Nomor 1.

Pelras, Christian. 1982. Manusia Bugis. Terjemahan oleh Abdul Rahman Abud dkk., 2005. Jakarta: Nalar bekerja sama Forum Jakarta-Paris, EFEO.

Penyusun. 1997. Ensiklopedi Islam 1. Jakarta: Ichtiar Baru Van Hoeve.

Rahim, A. Rahman. 2011. Nilai-Nilai Utama Kebudayaan Bugis. Yogyakarta: Penerbit Ombak.

Shihab, M. Quraish. 2005. Perempuan; Dari Cinta Sampai Seks, Dari Nikah Mut'ah sampai Nikah Sunnah, Dari Bias Lama sampai Bias Baru. Jakarta: Lentera Hati.

Syadzali, Munawir.1995. Dari Lembah Kemiskinan; Kontekstualisasi Ajaran Islam. Jakarta: IPHI dan Paramadina.

el Harakah Vol.15 No.2 Tahun 2013 
Tim Penulis Depdikbud. 2004. Masuknya Islam di Sulawesi Selatan dan Sulawesi Tenggara. Makassar: Balai Penelitian dan Pengembangan Agama.

Wajdi, Muhammad Faried, Anggota Tim Penulis Tafsir Berbahasa Bugis. Wawancara. tanggal 27 Juli 2010 di Makassar.

Yusuf, Muhammad. 2010. Perkembangan Tafsir al Quran di Sulawei Selatan (Studi Kritias Tafesere Akorang Mabbasa Ogi Karya Majelis Ulama Indonesia Sulawesi Selatan [Disertasi]. Makassar: PPs UIN Alauddin.

Yusuf, Muhammad. 2010. Metodologi Tafsir al Quran Berbahasa Bugis: Analisis Tafesere Akorang Mabbasa Ogi Karya MUI Sulsel. Sosio Ligia; Jurnal Ilmu Agama dan Ilmu Sosial. Volume 9, Edisi Khusus: 457- 460.

Yusuf, Muhammad. 2012. Bahasa Bugis dan Penulisan Tafsir di Sulawesi Selatan. Al Ulum, Jurnal Studi-Studi Islam. Volume 12, Nomor 1: 93. 